\title{
CHARACTERISTICS OF QUARTZ STONE POWDER BASED GEOPOLYMER MORTAR CURED AT AMBIENT CONDITION
}

\author{
Arass O. Mawlod ${ }^{1}$ and Rahel K. Ibrahim ${ }^{2}$ \\ ${ }^{1}$ Department of Civil Engineering, University of Raparin, Raniyah, Kurdistan Region, \\ Iraq. Email: arass.omer@uor.edu.krd \\ ${ }^{2}$ Department of Civil Engineering, Faculty of Engineering, Koya University, Koya, \\ Kurdistan Region, Iraq. Email: rahel.khalid@koyauniversity.org

\section{http://dx.doi.org/10.30572/2018/kje/120303}

\begin{abstract}
Development of self-curing geopolymers is a key consideration among the researchers. One of the challenges that face geopolymers to field application is applying of heat to enhance its mechanical properties. This study focuses on using self-cured, $\mathrm{NaOH}$ activated, quartz stone powder by using different cement dosages in producing geopolymer mortar. For this purpose twelve mixes were prepared. The base material, quartz stone powder, was replaced by Ordinary Portland Cement (OPC) in dosages of $(0 \%, 5 \%, 10 \%$, and $15 \%)$ by weight and different sodium hydroxide concentration variations were used. Compressive strength, water absorption and sorptivity were investigated. The results showed that $15 \%$ of OPC replacement has optimum influence on some properties of geopolymer mortar. At the same time Sodium hydroxide concentration of $14 \mathrm{M}$ achieves the optimum properties. The results revealed that incorporation of OPC and utilization of different $\mathrm{NaOH}$ concentrations significantly affected the compressive strength and absorption properties of the mortar.
\end{abstract}

KEYWORDS: Self-Curing, Geopolymer; Quartz Stone Powder; Compressive Strength; Water Absorption; Water Sorptivity. 


\section{INTRODUCTION}

Geopolymer is a new technology to replace ordinary Portland cement. Manufacturing process of cement is problematic to environment. Nearly $7 \%$ of emitted $\mathrm{CO}_{2}$ to atmosphere is due to OPC, which by turn leads to global warming (Andrew, 2018).

Geopolymers are produced by activating a source material containing silica and alumina with alkaline solutions. Industrial by-product materials and natural materials can be used as source geopolymer material. Industrial by-products like fly ash (Fernandez-Jimenez et al. 2006; Sindhunata et al., 2006; Kong and Sanjayan, 2010; Nematollahi et al., 2017) and ground granulated blast furnace slag (Bakharev et al. 1999; Shrestha et al., 2013) and natural materials like metakaolin (Davidovits, 1994) are possible materials for this purpose. Alkaline solution is a mixture of either sodium hydroxide and sodium silicate or potassium hydroxide and potassium silicate.

Geopolymer materials act as a sustainable material in two ways; recycling industrial by-product materials and reducing the exploitations of OPC like energy consumption, pollution and the area used to waste landfills (Behera et al., 2014). Most of the researchers mainly depend on industrial by-products to develop geopolymer materials, while these materials are not in sufficient amount to totally replace OPC, and not available in some countries. So it is so essential to examine different natural raw materials that mainly contain silica and alumina to produce geopolymer materials. Portland cement production requires a double amount of energy as compared to activator preparation in alkali activated production (Kong et al. 2006).

External heat supply is one of the limitations in the application of geopolymer because the chemical reaction of source material with alkaline solution is endothermic reaction (Bakharev, 2006), some additives can be used to enhance the polymerization process like, OPC, high calcium fly ash, calcium hydroxide and slag, as additional calcium sources in geopolymer mixes (Palomo et al., 2007; Chindaprasirt et al., 2011; Nath et al. 2012; Canfield et al., 2014; Suwan and Fan, 2014; Nath and Sarker, 2015; Aliabdo et al. 2016; Assi et al., 2016; Shehab et al. 2016). The reaction between cement and water is exothermic reaction, so it is an appropriate material to be used as an admixture for improving the polymerization process. Nano-silica incorporation in another way of geopolymerization improvement (Saini and Vattipalli, 2020).

Most commonly alkali activator is mixture of sodium silicate and sodium hydroxide, however preparing the sodium silicate needs $1300-1500^{\circ} \mathrm{C}$ that consumes a huge amount of energy (Kalapathy et al. 2002; Foletto et al., 2006), so developing geopolymer by utilizing just sodium hydroxide is an attempt to reduce the geopolymer energy consumption. 
Effect of OPC inclusion with levels of 5, 7.5 and $10 \%$ by weight of fly ash was explained by (Kaja et al. 2018). The results show that the optimum OPC substitution to fly ash is $7.5 \%$ at which the compressive strength is the highest. Wang et al., (2004) reported the impact of $\mathrm{NaOH}$ addition and curing temperature on the mechanical properties of hybrid binder composed of fly ash and cement kiln dust in paste sample. It was concluded that curing temperature was more effective for 50/50 fly ash/ cement kiln binder on strength enhancement than $\mathrm{NaOH}$ addition. Nath and Sarker, (2015) reported the influence of OPC inclusion to low calcium fly ash on the compressive strength of geopolymer mortar and concrete. It was achieved that the increase OPC content increases the compressive strength. Phoo-ngernkham et al. (2013) studied the impact of OPC addition to high calcium fly ash on mechanical and porosity properties of geopolymer concrete. It was revealed that the use of OPC as an additive to replace part of FA leads to improve compressive strength. Suwan and Fan (2014) studied the effect of OPC inclusion at levels of $5 \%, 10 \%, 30 \%, 50 \%$ and $70 \%$ of weight of fly ash and showed that the compressive strength continuously increased as replacement of OPC increases. Askarian et al. (2018) investigated the mechanical properties of one-part geopolymer fly ash replaced by $10 \%, 20 \%$ $30 \%$ and $60 \%$ of OPC. It was concluded that the compressive strength of hybrid binder was higher than the control geopolymer mixes furthermore it was reported that when OPC content increased from $10 \%$ to $60 \%$ the compressive strength also increases (Shehab et al. 2016) examined the impact of OPC inclusion in fly ash based geopolymer concrete. The authors concluded that $50 \%$ of OPC replacement retained the highest mechanical properties at 28 day.

This study has been performed in order to examine the feasibility of quartz stone powder as a base material of geopolymer. Literatures regarding the utility of quartz stone powder in producing geopolymer concrete are rare. So it is necessary to investigate the properties of geopolymers made by quartz stone powder as a base material. In this study quartz stone powder was used as a starting material and it was replaced by OPC at levels of $(0,5,10$ and 15$) \%$ to enhance the hardened properties of geopolymer mortar.

\section{METHODOLOGY}

\subsection{Materials}

\subsubsection{Quartz stone}

The quartz stones were collected and brought from Makok Mountain located west of Ranya city, cleaned by metal brush, crushed to a fine powder and sieved such that all the particles passed through $300 \mu \mathrm{m}$ sieve. The particle size distribution for the used quartz stone powder are shown in Fig. 1. 


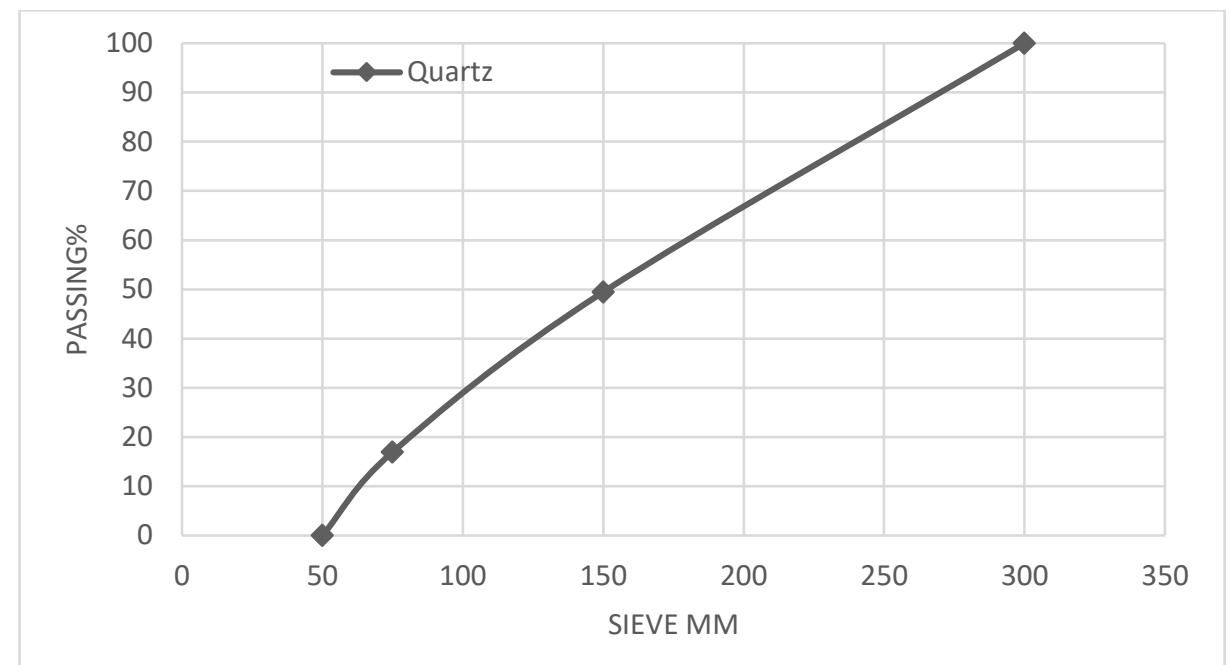

Fig. 1. Particle size distribution of quartz stone powder.

\subsubsection{Ordinary Portland cement}

Ordinary Portland cement was used for the entire experimental mixes of the study. The specific gravity of the cement was 3.14. The chemical and physical properties of the cement are shown in Tables 1 and 2 respectively, which are conformed to IQ.S 5/1984 standard for ordinary Portland cement.

Table 1. Chemical properties of cement (OPC).

\begin{tabular}{|c|c|c|}
\hline \multirow{2}{*}{ Chemical requirements } & \multicolumn{2}{|c|}{ IQ.S 5/1984 Standard for Ordinary Portland Cement } \\
\hline & Limitation & Test Results \\
\hline Lime saturation coefficient $\%$ & $0.66-1.02$ & 1.0 \\
\hline Magnesium Oxide (as $\mathrm{MgO}$ )\% & $\leq 5$ & 3.6 \\
\hline Sulfate content $\left(\right.$ as $\left.\mathrm{SO}_{3}\right) \%$ & $\begin{array}{l}2.5 \text { if } \mathrm{C} 3 \mathrm{~A} \leq 5 \\
2.8 \text { if } \mathrm{C} 3 \mathrm{~A} \geq 5\end{array}$ & 2.2 \\
\hline Loss of ignition (as LOI)\% & $\leq 4.0$ & 3.5 \\
\hline Non soluble substance $\%$ & $\leq 1.5$ & 0.8 \\
\hline
\end{tabular}

Table 2. Physical properties of cement (OPC).

\begin{tabular}{lcc}
\hline \multicolumn{1}{c}{ Physical Requirements } & $\begin{array}{c}\text { IQ.S 5/1984 Standard for Ordinary Portland } \\
\text { Cement }\end{array}$ & Test Result \\
\hline Fineness (Blaine) $\mathrm{kg} / \mathrm{m}^{2}$ & $\geq 230$ & 343 \\
-Initial setting time minute & $\geq 45$ & 150 \\
-Final setting time hour & $\leq 10$ & $3: 20$ \\
Soundness (expansion) $\%$ & $\leq 0.8$ & 0.2 \\
Compressive strength is not & $\geq 15.0$ & 35.7 \\
less than $\left(\mathrm{MN} / \mathrm{m}^{2}\right)$ & $\geq 23.0$ & 46.0 \\
\hline
\end{tabular}




\subsubsection{Fine aggregate}

Locally available river sand that conformed to ASTM C33 was used as a fine aggregate in saturated surface dry state. The specific gravity of the sand was 2.64 .

\subsubsection{Sodium Hydroxide}

Sodium hydroxide in flakes with purity of (99\%) was used for all of the experimental mixes for this research.

\subsubsection{Water}

Distilled water was used for preparing the $\mathrm{NaOH}$ solution.
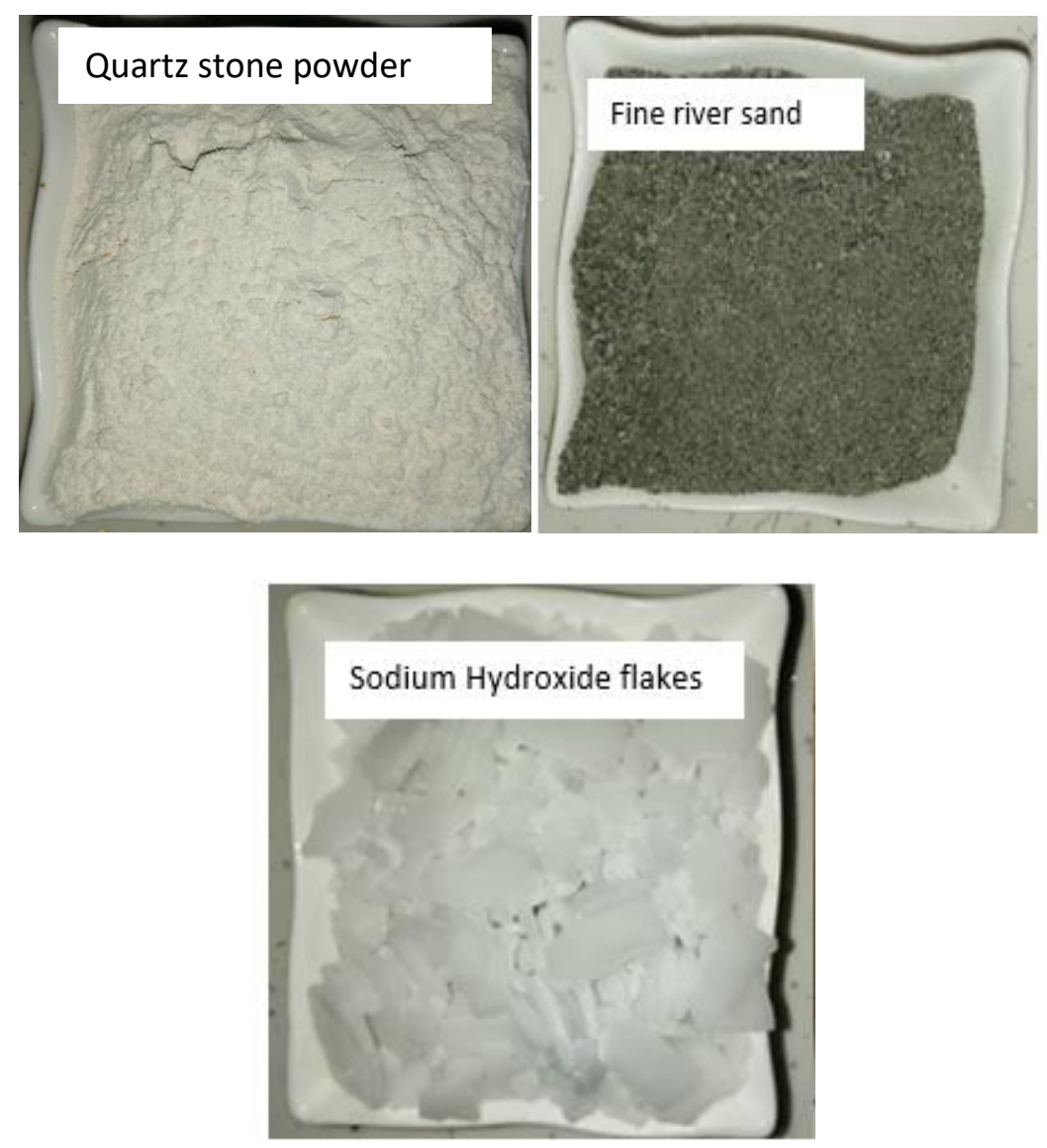

Fig. 2. Materials used in this research.

\subsection{Mix design}

Twelve geopolymer mixes were prepared. The quartz stone was replaced by ordinary Portland cement in percentages of $0 \%, 5 \%, 10 \%$ and $15 \%$ for each molar concentration (M10, M12 and M14) of sodium hydroxide. The solution of $\mathrm{NaOH}$ to binder ratio was remained constant 0.40 . Fine aggregate was used as $20 \%$ of the total weight of the mix. The mix proportions for the samples are shown in Table 3. 
Table 3. Mix proportion of the geopolymer mortar $\left(\mathrm{Kg} / \mathrm{m}^{3}\right)$.

\begin{tabular}{cccccccc}
\hline Mixes & $\begin{array}{c}\text { Proportion } \\
\text { of binders }\end{array}$ & $\begin{array}{c}\text { Quartz } \\
\text { powder }\end{array}$ & $\begin{array}{c}\text { Ordinary } \\
\text { Portland } \\
\text { Cement }\end{array}$ & $\begin{array}{c}\text { Fine } \\
\text { Sand }\end{array}$ & $\begin{array}{c}\text { NaOH } \\
\text { Molarit } \\
\mathbf{y}\end{array}$ & $\begin{array}{c}\text { NaOH } \\
\text { Solutio } \\
\text { n }\end{array}$ & $\begin{array}{c}\text { Binder/ } \\
\text { Solution }\end{array}$ \\
\hline M1 & Q100-C0 & 1215 & 0 & 467 & 10 & 486 & 0.40 \\
M2 & Q95-C5 & 1154.25 & 60.75 & 467 & 10 & 486 & 0.40 \\
M3 & Q90-C10 & 1093.5 & 121.5 & 467 & 10 & 486 & 0.40 \\
M4 & Q85-C15 & 1032.75 & 182.25 & 467 & 10 & 486 & 0.40 \\
M5 & Q100-C0 & 1215 & 0 & 467 & 12 & 486 & 0.40 \\
M6 & Q95-C5 & 1154.25 & 60.75 & 467 & 12 & 486 & 0.40 \\
M7 & Q90-C10 & 1093.5 & 121.5 & 467 & 12 & 486 & 0.40 \\
M8 & Q85-C15 & 1032.75 & 182.25 & 467 & 12 & 486 & 0.40 \\
M9 & Q100-C0 & 1215 & 0 & 467 & 14 & 486 & 0.40 \\
M10 & Q95-C5 & 1154.25 & 60.75 & 467 & 14 & 486 & 0.40 \\
M11 & Q90-C10 & 1093.5 & 121.5 & 467 & 14 & 486 & 0.40 \\
M12 & Q85-C15 & 1032.75 & 182.25 & 467 & 14 & 486 & 0.40 \\
\hline
\end{tabular}

\subsection{Mixing, Casting and Curing}

Sodium hydroxide flakes were dissolved in tap water to get the require concentration of solution. The binder materials (quartz stone powder partially replaced by cement by $0 \%, 5 \%$, $10 \%, 15 \%$ ) were manually blended, and then mixed with sand. The solution added to the dry materials and the mixture poured with two layers into $(25 \times 25 \times 25) \mathrm{mm}$ size molds. The moulds were manually compacted to remove the entrapped air. The samples were covered by a plastic bag to avoid moisture losing. After $24 \mathrm{hrs}$ the samples were de-molded and kept in ambient temperature. The samples were tested for compressive strength after 14, 28 and 56 and days of curing. For water absorption and water sorptivity 56 day cured samples were used. A total of 180 samples were prepared as shown in Fig. 3.
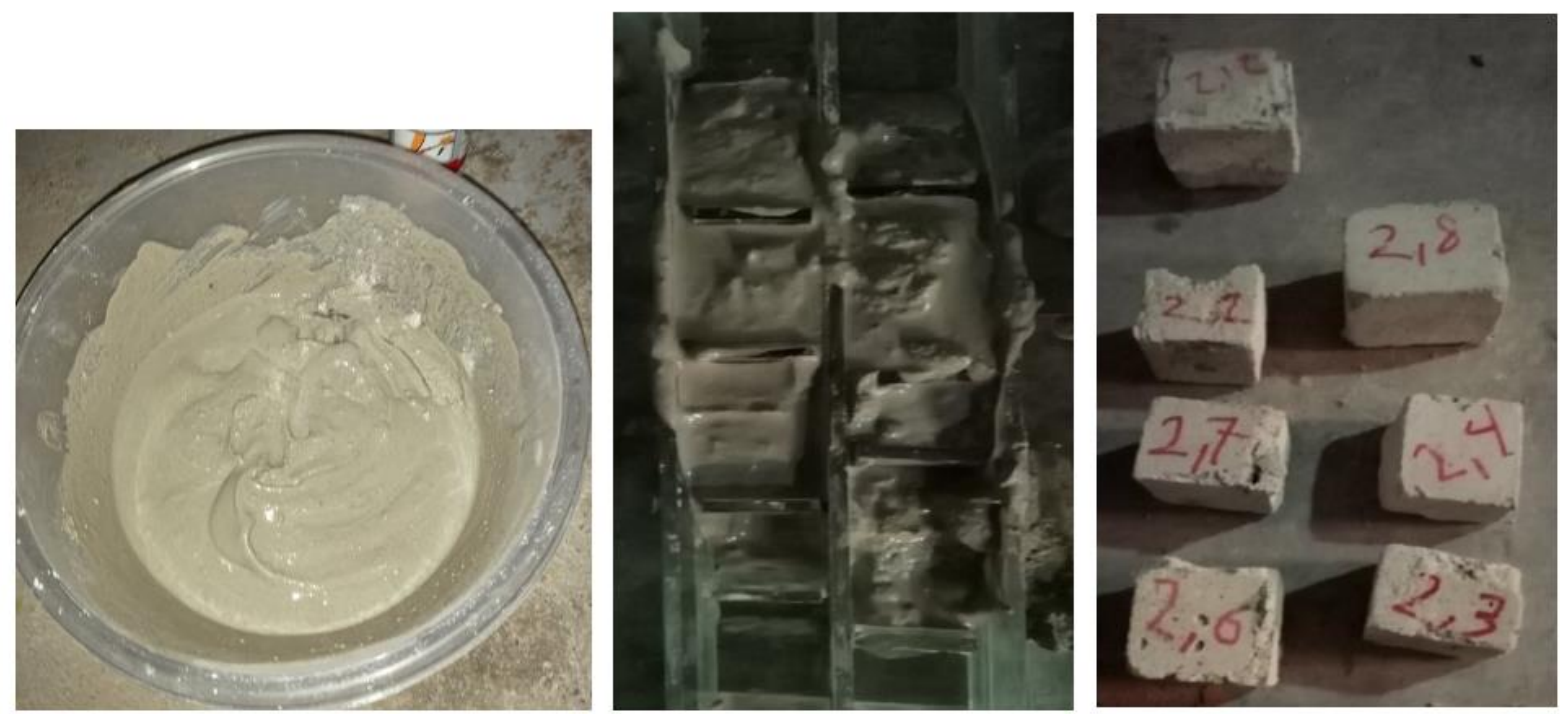

Fig. 3. Mixing, casting, and ambient curing of geopolymer mortar samples. 


\subsection{Testing}

\subsubsection{Compressive Strength}

The compressive strength test is conducted according to ASTM C109 (Standard, 2008) for cement mortar. For each mix three samples were tested by a digital compression machine with the capacity and sensitivity of $2000 \mathrm{kN}$ and $0.1 \mathrm{kN}$ respectively, (Fig. 4). The average of the results of three samples were calculated and reported.

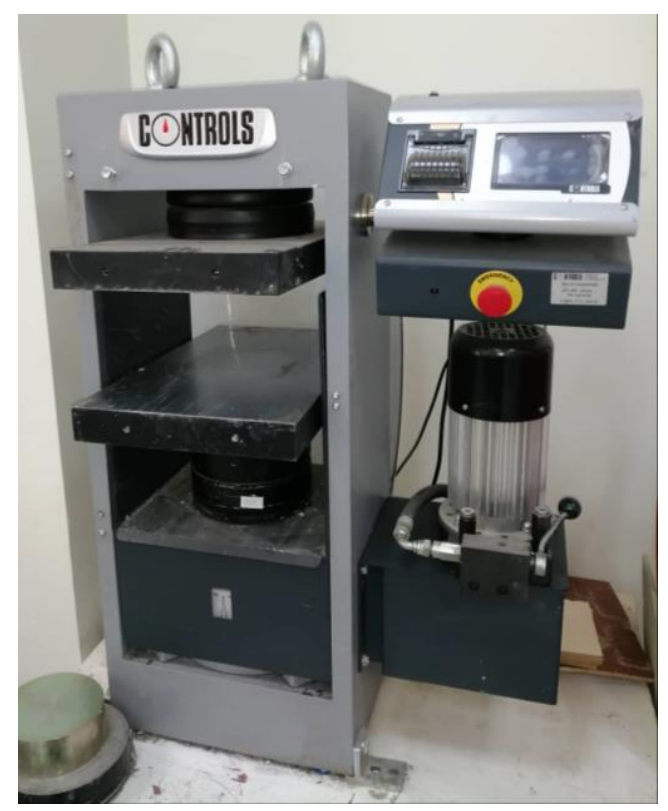

Fig. 4. Compression machine.

\subsubsection{Water absorption}

Water absorption is the ability of material to absorb water and retain under specific condition. Durability of materials can be evaluated by conducting water absorption test. In this research water absorption test was performed on 56 day cured samples. For each mix, three samples were dried to a constant mass in an electrical oven at $105^{\circ} \mathrm{C}$ for $24 \mathrm{hrs}$. The samples were kept to cool to room temperature, then immersed in water for $24 \mathrm{hrs}$. to get the saturated mass of the samples.

\subsubsection{Water sorptivity}

Water sorptivity is the ability of material to absorb water by suction. It is one of the tests related to the durability of the material to evaluate the ingress of water through the material. Water sorptivity of geopolymer mortar was carried out according to ASTM C1585 (Standard, 2011) standard. In this test three samples of $(25 \times 25 \times 25) \mathrm{mm}$ were used. In this study for each mix three samples were dried to a constant mass at $105^{\circ} \mathrm{C}$ in oven at 56 day, then the samples were taken out, and coated with silicone sealing to avoid entering of water from the sides, then the 
samples kept in water with depth not more than $4 \mathrm{~mm}$ above the bottom of the samples as shown in the Fig. 5. Wetted height of the sample can be evaluated by dividing the increase of the mass of the sample weighed at different time intervals, by the bottom surface area of the sample and density of water. Then, the square root of time versus these values was plotted and the sorptivity index of mortar was calculated by the slope of the line of the best fit.

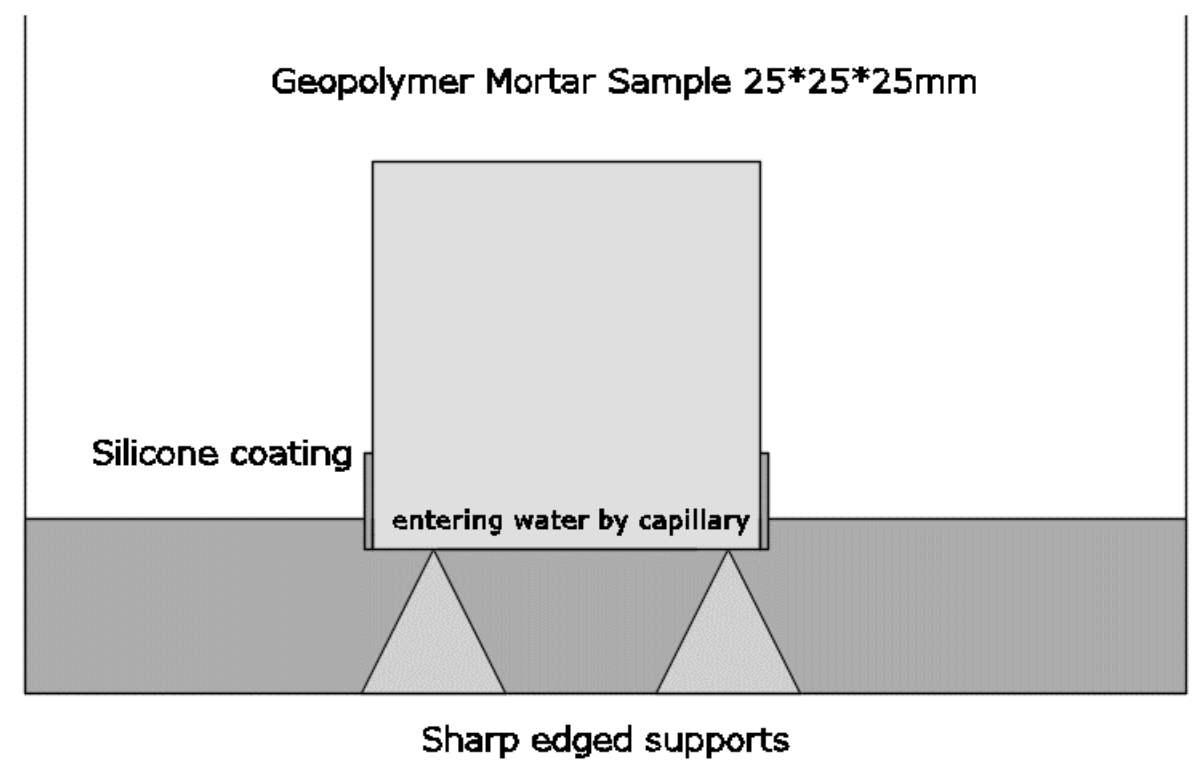

Fig. 5. Water sorptivity test for geopolymer mortar.

\section{RESULTS AND DISCUSSION}

\subsection{Compressive strength}

Table 4 and Fig. 6 show the results the compressive strength. It is obvious that with increasing the OPC content from $0 \%$ to $15 \%$ the compressive strength increases from $6.15 \mathrm{MPa}$ to $7.93 \mathrm{MPa}$ at 28 days for $14 \mathrm{M}$ concentration of $\mathrm{NaOH}$. The study conducted by Phoo-ngernkham et al., (2013) who partially replaced OPC up to $15 \%$ by weight of high calcium fly ash, supports obtained results.

Previous studies agree with this investigation (Guo et al., 2010; Garcia-Lodeiro et al., 2011) Cement contains high amount of $\mathrm{Ca}$ which results in high compressive strength, this because of formation of additional of C-S-H and C-A-S-H gels that alters the microstructure of the material. New gels of geopolymeric binder CS-H and C-A-S-H work as a micro-aggregate, thereby improved the durability and compressive strength (Yip and Van Deventer, 2003; Yip, Lukey and Van Deventer, 2005). The reaction with $\mathrm{SiO}_{2}$ and $\mathrm{Al}_{2} \mathrm{O}_{3}$ of binder reduced the $\mathrm{Ca}(\mathrm{OH})_{2}$ content of the system, and the pore structure was refined in a similar way as the pozzolanic reaction in the blended cement paste (Kroehong et al., 2011). 
At the same time increasing the concentration of $\mathrm{NaOH}$ up to $14 \mathrm{M}$ led to additional increase in compressive strength. This is due to the high degree of geopolymerization as a result of increased leaching of alumina and silica (Hanjitsuwan et al., 2014).

Table 4. Effect of OPC replacement and $\mathrm{NaOH}$ concentration variation on compressive strength.

\begin{tabular}{|c|c|c|c|c|c|c|c|c|c|}
\hline \multirow{3}{*}{ Mixes } & \multicolumn{9}{|c|}{ Compressive Strength MPa } \\
\hline & \multicolumn{3}{|c|}{14 Day } & \multicolumn{3}{|c|}{28 Day } & \multicolumn{3}{|c|}{56 Day } \\
\hline & M10 & M12 & M14 & M10 & M12 & M14 & M10 & M12 & M14 \\
\hline Q100C0 & 4.08 & 4.36 & 4.81 & 5.12 & 5.48 & 6.15 & 5.41 & 5.94 & 7.47 \\
\hline Q95C5 & 4.31 & 5.73 & 5.98 & 5.35 & 5.86 & 6.2 & 5.44 & 6.88 & 7.91 \\
\hline Q90C10 & 5.57 & 6.02 & 6.09 & 6.53 & 6.75 & 6.78 & 7.47 & 7.58 & 8.2 \\
\hline Q85C15 & 5.67 & 7.04 & 7.16 & 7.23 & 7.89 & 7.93 & 8.35 & 8.99 & 9.06 \\
\hline
\end{tabular}

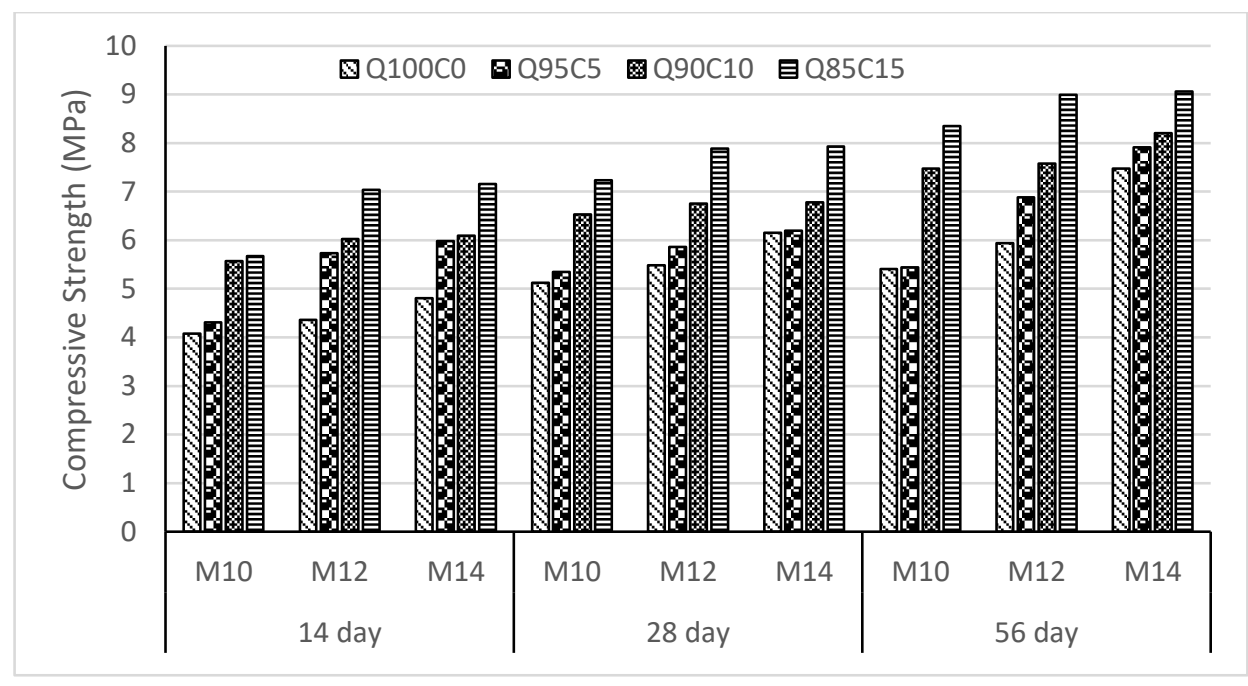

Fig. 6. Effect of $\mathrm{OPC}$ replacement and $\mathrm{NaOH}$ concentration variation on compressive strength of quartz stone powder- based mortar.

\subsection{Water absorption}

The results of the water absorption are shown in the Table 5 and Fig. 7. Increasing OPC content resulted in a better gel formation that led to a denser microstructure. This is the result of the reduction of water absorption when OPC content increased from $10.87 \%$ to $7.19 \%$ for M14 concentration of $\mathrm{NaOH}$ at 56 day. The reaction with $\mathrm{SiO}_{2}$ and $\mathrm{Al}_{2} \mathrm{O}_{3}$ of binder reduced the $\mathrm{Ca}(\mathrm{OH})_{2}$ content of the system, and the pore structure was refined in a similar way as the pozzolanic reaction in the blended cement paste (Kroehong et al., 2011). The results well corresponded with the mechanical behavior.

On the other hand, increasing the concentration of $\mathrm{NaOH}$ led to high degree of geopolymerization (Hanjitsuwan et al., 2014) this produce a denser gel that minimize the amount of absorbed water by the samples. 
Table 5. Effect of OPC replacement and $\mathrm{NaOH}$ concentration variation on water absorption of quartz stone powder- based mortar.

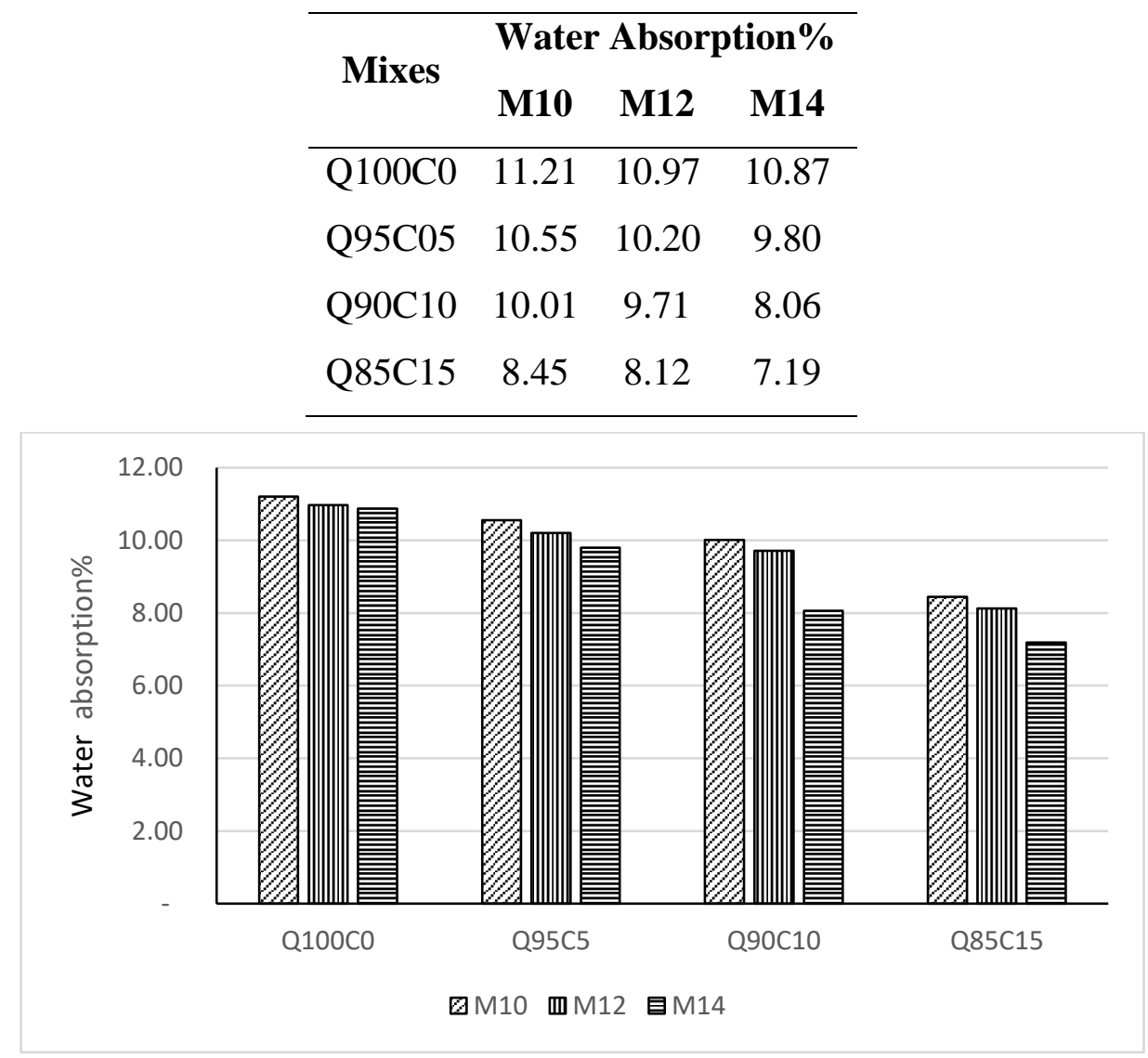

Fig. 7. Effect of OPC replacement and $\mathrm{NaOH}$ concentration variation on water absorption of quartz stone powder- based mortar.

\subsection{Water Sorptivity}

The results of the water sorptivity are shown in the Figs. 8. a, b and c. Increasing OPC content resulted in a better gel formation that led to a more dense microstructure. This is the result of the reduction of water absorption when OPC content increased. The reaction with $\mathrm{SiO}_{2}$ and $\mathrm{Al}_{2} \mathrm{O}_{3}$ of binder reduced the $\mathrm{Ca}(\mathrm{OH})_{2}$ content of the system, and the pore structure was refined in a similar way as the pozzolanic reaction in the blended cement paste (Kroehong et al., 2011). The results well corresponded with the mechanical behavior.

On the other hand, increasing the concentration of $\mathrm{NaOH}$ led to high degree of geopolymerization (Hanjitsuwan et al., 2014) this produce a denser gel that minimize the amount of suction water by capillary action. 

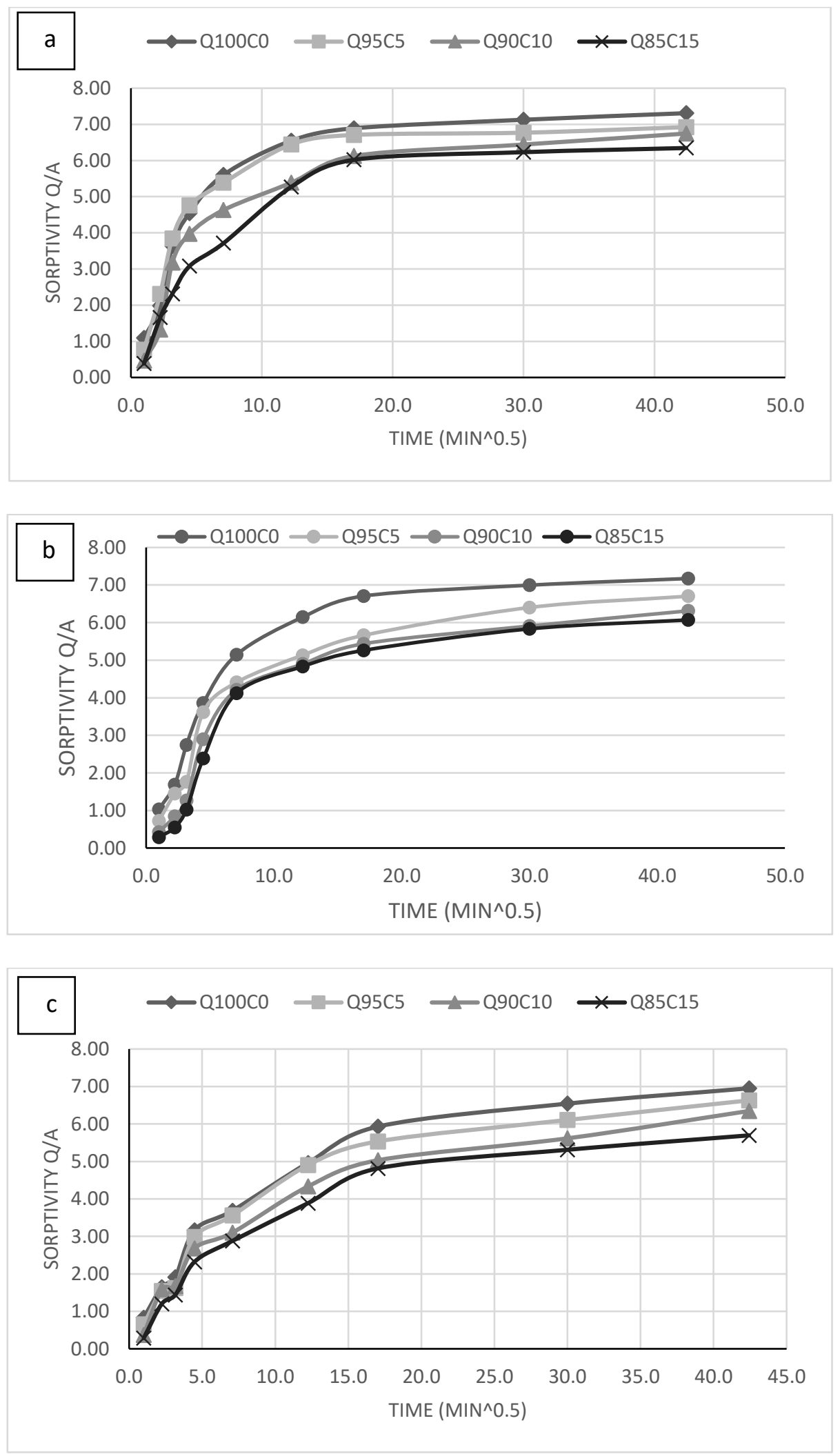

Fig. 8. Effect of OPC replacement and $\mathrm{NaOH}$ concentration variation on compressive strength of quartz stone powder- based mortar. a) $10 \mathrm{M}$, b) $12 \mathrm{M}$, c) $14 \mathrm{M}$. 


\section{CONCLUSION}

On the basis of the results achieved in this study, the followings can be concluded.

1. The incorporation of OPC increases the compressive strength of geopolymer mortar. This is due to the formation of additional gel C-S-H and C-A-S-H which alters the microstructure of the mortar. When OPC content increased from $0 \%$ to $15 \%$, compressive strength approximately increased by $41 \%$. Simultaneously, increasing $\mathrm{NaOH}$ concentration leads to increase compressive strength. When $\mathrm{NaOH}$ molarity increased from $12 \mathrm{M}$ to $14 \mathrm{M}$, compressive strength approximately increased by $20 \%$

2. The use of OPC to partially replace quartz stone powder in the mixes leads to decrease water absorption. When OPC content increased from $0 \%$ to $15 \%$, water absorption approximately decreased by $28 \%$. That is well corresponded with mechanical behavior. At the same time increasing $\mathrm{NaOH}$ concentration leads to lower water absorption. When $\mathrm{NaOH}$ molarity increased from $12 \mathrm{M}$ to $14 \mathrm{M}$, water absorption approximately decreased by $11 \%$

3. Increasing OPC content in the mixes leads to lower water sorptivity. At the same time increasing $\mathrm{NaOH}$ concentration leads to decrease water sorptivity.

\section{RECOMMENDATION}

The authors recommend researchers to take beyond $15 \%$ of base material replacement.

\section{REFERENCES}

Andrew, R. M. (2018) 'Global $\mathrm{CO}_{2}$ emissions from cement production', Earth System Science Data, 10(1), p. 195.

Askarian, M. et al. (2018) 'Mechanical properties of ambient cured one-part hybrid OPCgeopolymer concrete', Construction and Building Materials, 186, pp. 330-337.

Assi, L. et al. (2016) 'Improvement of the early and final compressive strength of fly ash-based geopolymer concrete at ambient conditions', Construction and Building Materials, 123, pp. 806-813.

Bakharev, T. (2006) 'Thermal behaviour of geopolymers prepared using class F fly ash and elevated temperature curing', Cement and Concrete Research, 36(6), pp. 1134-1147.

Bakharev, T., Sanjayan, J. G. and Cheng, Y.-B. (1999) 'Alkali activation of Australian slag cements', Cement and Concrete Research, 29(1), pp. 113-120. 
Behera, M. et al. (2014) 'Recycled aggregate from C\&D waste \& its use in concrete--A breakthrough towards sustainability in construction sector: A review', Construction and building materials, 68, pp. 501-516.

Canfield, G. M. et al. (2014) 'The role of calcium in blended fly ash geopolymers', Journal of materials science, 49(17), pp. 5922-5933.

Chindaprasirt, P. et al. (2011) 'High-strength geopolymer using fine high-calcium fly ash', Journal of Materials in Civil Engineering, 23(3), pp. 264-270.

Davidovits, J. (1994) 'High-alkali cements for 21 st century concretes', Special Publication, 144, pp. 383-398.

Fernandez-Jimenez, A. M., Palomo, A. and Lopez-Hombrados, C. (2006) 'Engineering properties of alkali-activated fly ash concrete', ACI Materials Journal, 103(2), p. 106.

Foletto, E. L. et al. (2006) 'Conversion of rice hull ash into soluble sodium silicate', Materials Research, 9(3), pp. 335-338.

Garcia-Lodeiro, I. et al. (2011) 'Compatibility studies between NASH and CASH gels. Study in the ternary diagram Na2O--CaO--A12O3--SiO2--H2O', Cement and Concrete Research, 41(9), pp. 923-931.

Guo, X. et al. (2010) 'Alkali-activated complex binders from class C fly ash and Ca-containing admixtures', Journal of Hazardous Materials, 173(1-3), pp. 480-486.

Hanjitsuwan, S. et al. (2014) 'Effects of $\mathrm{NaOH}$ concentrations on physical and electrical properties of high calcium fly ash geopolymer paste', Cement and Concrete Composites, 45, pp. 9-14.

Kaja, A. M., Lazaro, A. and Yu, Q. L. (2018) 'Effects of Portland cement on activation mechanism of class F fly ash geopolymer cured under ambient conditions', Construction and Building Materials, 189, pp. 1113-1123. doi: 10.1016/j.conbuildmat.2018.09.065.

Kalapathy, U., Proctor, A. and Shultz, J. (2002) 'An improved method for production of silica from rice hull ash', Bioresource technology, 85(3), pp. 285-289.

Kong, D. L. Y. and Sanjayan, J. G. (2010) 'Effect of elevated temperatures on geopolymer paste, mortar and concrete', Cement and concrete research, 40(2), pp. 334-339.

Kong, D., Sanjayan, J. and Sagoe-Crentsil, K. (2006) 'The behaviour of geopolymer paste and concrete at elevated temperatures'. 
Kroehong, W. et al. (2011) 'Effect of palm oil fuel ash fineness on the microstructure of blended cement paste', Construction and Building Materials, 25(11), pp. 4095-4104.

Liabdo, A. A., Elmoaty, A. E. M. A. and Salem, H. A. (2016) 'Effect of cement addition, solution resting time and curing characteristics on fly ash based geopolymer concrete performance', Construction and building materials, 123, pp. 581-593.

Nath, P. and Sarker, P. K. (2015) 'Use of OPC to improve setting and early strength properties of low calcium fly ash geopolymer concrete cured at room temperature', Cement and concrete composites, 55, pp. 205-214.

Nath, P., Sarker, P. K. and others (2012) 'Geopolymer concrete for ambient curing condition', in Australasian Structural Engineering Conference 2012: The past, present and future of Structural Engineering, p. 225.

Nematollahi, B. et al. (2017) 'High ductile behavior of a polyethylene fiber-reinforced one-part geopolymer composite: A micromechanics-based investigation', Archives of Civil and Mechanical Engineering, 17, pp. 555-563.

Palomo, A. et al. (2007) 'OPC-fly ash cementitious systems: study of gel binders produced during alkaline hydration', Journal of Materials Science, 42(9), pp. 2958-2966.

Phoo-ngernkham, T. et al. (2013) 'Properties of high calcium fly ash geopolymer pastes with Portland cement as an additive', International Journal of Minerals, Metallurgy, and Materials, 20(2), pp. 214-220.

Saini, G. and Vattipalli, U. (2020) 'Assessing properties of alkali activated GGBS based selfcompacting geopolymer concrete using nano-silica', Case Studies in Construction Materials, p. e00352.

Shehab, H. K., Eisa, A. S. and Wahba, A. M. (2016) 'Mechanical properties of fly ash based geopolymer concrete with full and partial cement replacement', Construction and Building Materials, 126, pp. 560-565.

Shrestha, R. et al. (2013) 'Mechanical Properties of Geopolymer Concrete: Applicability of Relationships Defined by AS 3600', in Concrete Institute of Australia-Biennial Conference.

Sindhunata et al. (2006) 'Effect of curing temperature and silicate concentration on fly-ashbased geopolymerization', Industrial \& Engineering Chemistry Research, 45(10), pp. 35593568 . 
Standard, A. (2008) 'ASTM C109-standard test method for compressive strength of hydraulic cement mortars', ASTM International, West Conshohocken, PA.

Standard, A. (2011) 'C1585', Standard Test Method for Measurement of Rate of Absorption of Water by Hydraulic-Cement Concretes. ASTM International, West Conshohocken, Pennsylvania.

Suwan, T. and Fan, M. (2014) 'Influence of OPC replacement and manufacturing procedures on the properties of self-cured geopolymer', Construction and Building Materials, 73, pp. 551561. doi: 10.1016/j.conbuildmat.2014.09.065.

Wang, K., Shah, S. P. and Mishulovich, A. (2004) 'Effects of curing temperature and $\mathrm{NaOH}$ addition on hydration and strength development of clinker-free CKD-fly ash binders', Cement and Concrete Research, 34(2), pp. 299-309.

Yip, C. K. and Van Deventer, J. S. J. (2003) 'Microanalysis of calcium silicate hydrate gel formed within a geopolymeric binder', Journal of Materials Science, 38(18), pp. 3851-3860.

Yip, C. K., Lukey, G. C. and Van Deventer, J. S. J. (2005) 'The coexistence of geopolymeric gel and calcium silicate hydrate at the early stage of alkaline activation', Cement and concrete research, 35(9), pp. 1688-1697. 